\title{
Pengakuan terhadap Masyarakat Hukum Adat Marga Sarampas dan Penguasaan Hak Atas Tanahnya
}

\author{
Hendra Herman \\ Magister Hukum Universitas Muhammadiyah Yogyakarta \\ Jl. Brawijaya Kasihan Kab. Bantul Prov. DI Yogyakarta \\ Correspondence email: hendraherman2010@gmail.com
}

\begin{abstract}
Abstrak. Putusan Mahkamah Konsitusi Nomor 35/PUU-X/2012 berimplikasi pada pengakuan negara terhadap hak-hak tradisional Masyarakat Hukum Adat berupa hutan adat yang selama ini terbaikan. Penelitian ini ditujukan untuk mengetahui kedudukan Masyarakat hukum adat Marga Sarampas dalam penguasaan hak atas tanah. Masalah yang dikaji dalam penelitian ini adalah (1) bagaimana pengakuan terhadap MHA Marga Sarampas; (2) bagaimana penguasaan hak atas tanah MHA Marga Sarampas.
\end{abstract}

Kata kunci: Masyarakat hukum adat marga sarampas; hak-hak tradisional; penguasaan atas tanah.

Abstract. The decision of the Constitutional court (MK) Numbere 35/PUU-X/2012 has implications for state recognition of the traditional rights of indigenous peoples in the form of custimary forests which have have been neglected. The study aims to determine the legal position of the indigenous people of Marga Sarampas in controlling their land rights. The formulation of the problems raised in this research are (1) how is the recognition and protection of the indigenous peoples of Marga Sarampas; (2) how the rights to land of the indigenous people of Marga Sarampas.

Keywords: the indigenous people of Marga Sarampas; traditional rights; control of land

\section{PENDAHULUAN}

Undang Undang Dasar Tahun 1945 dan berbagai peraturan dibawahnya telah memberikan pengakuan terhadap keberadaan Masyarakat Hukum Adat (MHA). Pasal 18B ayat (2) UUD 1945 menegaskan bahwa kesatuan-kesatuan masyarakat hukum adat beserta hak-hak tradisionalnya sepanjang masih hidup di akui dan dihormati oleh Negara sesuai prinsip negara kesatuan Republik Indonesia yang diatur dalam Undang-Undang.

Keberadaan Pasal 18B ayat (2) UUD 1945 serta undang-undang sektoral seperti UU No. 41 tahun 1999 Kehutanan serta UU sektoral lainnya telah berupaya memberikan pengakuan dan penghormatan terhadap kesatuan MHA. ${ }^{1}$ Pengakuan itu berupa MHA dilindungi hak tradisionalnya serta diakui sebagai subjek hukum. ${ }^{2}$ Salah satu bentuk nyata dari hak MHA adalah hak kepemilikan terhadap tanah adat atau yang sering disebut dengan tanah ulayat. $^{3}$

Presiden Susilo Bambang Yudhoyono, dalam suatu forum internasional di Jakarta tanggal 27 Juni 2013, Tropical Forest Aliance 2020 : Promotion Suistainability and Productivti in the Palm Oil and Pulp \& Paper Sector Workshop, menyatakan sikapnya untuk melakukan proses pendaftaran hak atas tanah dan wilayah adat MHA di Indonesia. Komitmen Presiden merupakan respon atas putusan Mahkamah Konsitusi (MK) Nomor 35/PUU-X/2012, yang memutuskan hutan adat adalah bagian dari wilayah adat tidak/bukan lagi hutan negara. ${ }^{4}$ Putusan Mahkamah Konsitusi menjadikan dasar bagi pengakuan hak MHA atas wilayah, tanah serta pengelolaan sumberdaya.

Dalam Putusan tersebut, MK memutuskan bahwa beberapa pasal dalam Undang-Undang No. 41 Tahun 1999 tentang Kehutanan bertentangan dengan UUD 1945. Sehingga memberikan konsekuensi dan konstruksi baru terhadap perlindungan hak adat yang sangat berbeda dengan model lama. ${ }^{5}$ Selain itu, putusan MK tersebut menjadi penyemangat MHA dalam proses perjuangan panjang atas wilayah adatnya termasuk hutan adat. Dengan demikian,

${ }^{1}$ Jawahir Thontowi, Pengaturan Masyarakat Hukum Adat Dan Implentasi Perlindungan Hak-Hak Tradisionalnya, Jurnal Hukum IUS QUIA IUSTUM, Vol. 1 No. 20, 2013, Hal 2.

${ }^{2}$ Safrin Salam, Perlindungan Hukum Masyarakat Hukum Adat Atas Hutan Adat, Jurnal Hukum Novelty, Vol. 7, No. 2, 2016, hal. 210.

${ }^{3}$ Zayanti Mandasari, Politik Hukum Pengaturan Masyarakat Hukum Adat (Studi Putusan Mahkamah Konsitusi), Jurnal IUSQUIAIUSTUM, Volume 21 Nomor 2, 2014, hal. 229.

${ }^{4}$ Dyah Ayu Widowati, dkk, Pengakuan Dan Perlindungan Hak Atas Tanah Masyarakat Hukum Adat Di Kawasan Hutan, Yogyakarta: Amongkarta, 2014, hal. 1

${ }^{5}$ Faaiq Tobronii, MenguatkanHakMasyarakat Adat Atas Hutan Adat (Studi Putusan Mahkamah Konsitusi Nomor 35/PUUX/2012), Jurnal Konsitusi : Volume10, Nomor 3. 2013. hal. 1. 
pengakuan resmi negara yang menjadikan hutan adat wilayah dari hutan negara dianulir melalui oleh MK. Sehingga, wilayah adat termasuk hutan adat melalui dikembalikan pengelolaannya kepada MHA. ${ }^{6}$

Sesuai Pasal 67 UU Kehutanan, untuk dapat diakui sebagai MHA di tetapkan dengan Peraturan Daerah. Dan untuk wilayah adatnya sebagai objek diajukan ke Menteri LHK untuk ditetapkan sebagai hutan hak bagi masyarakat adat yang bersangkutan. Seperti halnya MHA Marga Sarampas yang berada di Kabupaten Merangin secara legal formal telah diakui dalam Perda Kabupaten Merangin Nomor 8 Tahun 2016 Tentang Pengakuan Dan Perlindungan MHA Marga Sarampas. Substansi dari Peraturan Daerah tersebut bermakna pengumuman, pengakuan dan perlindungan bagi hak-hak tradisional MHA Sarampas yang tidak diakui selama ini diantaranya hak atas tanah. Dengan adanya Perda tersebut, diharapkan hak-hak MHA Marga Sarampas dapat diberikan dan menjadi landasan hukum untuk melakukan pembangunan serta pemberdayaan di wilayah adat Sarampas.

Bagi MHA, tanah adalah sumber kehidupan bukan hanya sekadar sumber ekonomi. Beragam ritual adat dilaksanakan sebagai bentuk hubungan spritual MHA dengan alam. Sejarah politik agraria yang terjadi telah menimbulkan dampak pada hancurnya tatanan kehidupan MHA secara keseluruhan dan pengabaian atas hubungannya dengan tanah. ${ }^{7}$

Berdasarkan uraian dari latar belakang diatas, yang akan dibahas dalam penulisan ini adalah

1. Bagaimana pengakuan terhadap MHA Marga Sarampas?

2. Bagaimana penguasaan hak atas tanah MHA Marga Sarampas ?

\section{METODE}

\section{Pendekatan Penelitian}

Penelitian ini menggunakan pendekatan hukum doktrinal (normatif) yaitu penelitian hukum yang meletakkan hukum sebagai sebuah bangunan sistem norma. Sistem norma yang dimaksud adalah mengenai asas-asas, norma, kaidah dari peraturan-peraturan-peraturan, putusan-putusan pengadilan, perjanjian serta doktrin (ajaran). ${ }^{8}$

\section{Sumber Data Dan Alat Pengumpulan Data}

Sumber data dalam penelitian ini yaitu studi kepustakaan dengan melakukan serangkaian kegiatan membaca, mengutip, mencatat buku-buku, menelaah perundang-undangan yang berkaitan dengan permasalahan penelitian. Sumber data diperoleh dari bahan perpustakaan atau literatur yang mempunyai kaitan dengan objek penelitian. ${ }^{9}$

\section{Analisa Data}

Analisis data kualitatif dalam penelitian ini dilakukan secara induktif, yaitu cara berfikir yang bertolak dari pengetahuan-pengetahuan yang bersifat khusus/tertentu atau fakta-fakta yang bersifat individual yang dirangkai untuk ditarik kesimpulan yang bersifat umum. ${ }^{10}$

\section{HASIL DAN PEMBAHASAN \\ Pengakuan Terhadap Masyarakat Hukum Adat Marga Serampas}

Pasca pemberlakuan UU No. 5 Tahun 1979 terjadi persamaan bentuk pemerintahan desa di Indonesia. UU ini tidak memperhatikan bentuk administrasi pemerintahan yang sudah ada dan telah lama digunakan oleh komunitas MHA seperti Marga Sarampas. Akibatnya lembaga adat MHA Marga Sarampas tidak menempatkan kedudukan penting dalam mengatur pemerintahan dilingkup desa terutama aturan kepemilikan tanah/hutan adat menjadi lemah ataupun hilang sehingga tanah/hutan adat banyak berubah status menjadi tanah milik pribadi atau negara. Perubahan status hukum membuat MHA Marga Sarampas kehilangan hak (kolektif) mereka atas tanah/hutan adat yang beralih dikuasai negara. Ketika Negara menyerahkan hak pengelolaan hutan kepada perusahana melalui hak penguasaan hutan (HPH) maka Marga Sarampas menjadi lemah secara hukum untuk mempertahankannya.

Untuk itu, pengakuan MHA melalui Perda menjadi sangat penting agar mempunyai kedudukan hukum. Jika dilihat dari UU Kehutanan, agar mendapatkan pengakuan sebagai MHA harus memenuhi 2 (dua) kriteria yaitu sepanjang masih ada dan diakui keberadaannya. MHA Marga Sarampas yang berada di Kabupaten Merangin telah memenuhi unsur yang termaktub dalam UU Kehutanan untuk diakui sebagai MHA, yaitu:

\section{${ }^{6}$ Widiyanto, Menyegarakan Ketetapan Wilayah/Hutan Adat : Profil MHA Untuk Implementasi Putusan MK No. 35 Tahun} 2012, Jakarta : HuMa, 2019 hlm. 3.

${ }^{7}$ Komisi Nasional Hak Asasi Manusia, Inkuiri Nasional Komnas HAM: Hak Masyaarakat Hukum Adat Atas Wilayah nya diKawasan Hutan, Jakarta: Komisi Nasional Hak Asasi Manusia, 2016. hal. 25.

${ }^{8}$ Mukti Fajar N Dan Yulianto Ahmad, Dualisme Penelitian Hukum Normativ Dan Empiris, Yogyakarta: Pustaka Pelajar, 2017. hlm. 34.

${ }^{9}$ Ishaq,Metode Penelitian Hukum Dan Penulisan Skripsi, Thesis Serta Disertasi. Bandung: CV. Alfabeta, 2017. Hal. 99100.

\footnotetext{
${ }^{10}$ Mukti Fajar N Dan Yulianto Achmad, Op.Cit., hal. 113.
} 
1. Sepanjang masih ada

MHA Marga Serampas merupakan salah satu komunitas adat yang eksistensinya masih ada hingga saat ini. Marga Sarampas berada di lima desa, yakni Desa Renah Kemumu, Tanjung Kasri, Lubuk Mentilin, Rantau Kermas dan Renah Alai.

2. Diakui keberadannya

Keberadaan MHA Marga Sarampas telah diakomodir di dalam Perda Kab. Merangin No. 8 Tahun 2016. Dalam Pasal 1 angka 7 Perda tersebut dijelaskan bahwa MHA Marga Serampas adalah sekelompok masyarakat yang turun-temurun bermukim di daerah geografi Kabupaten Merangin dan mempunyai hubungan pada asal usul nenek moyang, adanya kaitan yang kuat dengan tanah, wilayah dan SDA di daerah adatnya dan mempunyai sistem nilai dalam menentukan corak kegiatan ekonomi, sosial dan politik.

Dengan demikian, tujuan pengakuan dan perlindungan terhadap MHA Marga Serampas yang ditetapkan dengan perda yaitu (1) eksistensi dan hak-hak MHA Marga Serampas wajib diakui oleh semua pihak dan dilindungi secara hukum; (2) Pemerintah Kabupaten Merangin bertanggung jawab terhadap pemberdayaan MHA Marga Serampas beserta hak-hak tradisionalnya. Sehingga bisa menjadi jembatan penyelesaian konflik dengan pengelola TNKS.

MHA Marga Sarampas yang bermukim di lima desa dalam Kabupaten Merangin berada di wilayah Taman Nasional Kerinci Sebelat (TNKS) sehingga sering menimbulkan konflik dengan negara. Hal ini dilatar belakangi oleh penetapan kawasan TNKS yang ditetapkan menjadi taman nasional melalui Keputusan Menhutbun No. 901/Kpts/1999 tanggal 14 Oktober 1999. Namun jauh sebelumnya proses penetapannya sudah dimulai sejak tahun 1982. Puncaknya tahun 1992 Bupati Sarolangun Bangko (sekarang Merangin) meminta dua Desa Marga Sarampas untuk direlokasi yaitu Desa Tanjung Kasri dan Desa Renah Kemumu, tetapi belum mendapat persetujuan dari Pemerintah Pusat hingga saat ini. Sebagai masyarakat lokal justru MHA Marga Sarampas telah mengelola tanah untuk pertanian sebelum ada Taman Nasional Kerinci Seblat (TNKS) disahkan dengan pembagian wilayah pemanfaatan dan perlindungan area secara adat. ${ }^{11}$

Selain Marga Serampas, di Kab. Merangin juga terdapat Suku Kubu (SAD) yang keberadaannya belum diakui sebagai MHA. Suku Kubu tidak mempunyai wilayah tetap seperti halnya MHA Marga Sarampas yang mempunyai wilayah tetap. Hal ini dikarenakan Suku Kubu hidupnya berpindah-pindah (nomaden) dari satu tempat ke tempat lainnya. Sehingga faktor inilah yang membuat eksistensi Suku Kubu tidak dapat ditetapkan sebagai Masyarakat Hukum Adat (MHA).

Menurut Jeane, keberadaan MHA dan hak-haknya didalam kaitannya dengan pengakuan dan pengaturannya undang-undang, kesatu yang dilaksanakan adalah memposisikan dan kedudukan MHA itu sebagai subjek hukum yang memiliki hak dan kewajiban dalam Negara Kesatuan Republik Indonesia. Apakah Negara mengakui dan menghormati atau tidak kepada keberadaanatau dengan hak-hak tradisional yang berada kepadanya. Kedua, selanjutnya yang harus dilaksanakan adalah hak- hak adat atas objek yang berada pada MHA. Apakah hak-hak adat mereka masih ada, di akui, di hormati dan di lindungi juga. Secara normatif bentuk-bentuk pengakuan, penghormatan dan perlindungan hukum dapat digali dan di temukan dalam penerapan kehidupan sehari-hari. ${ }^{12}$

Hak tersebut berupa hak mengelola sumber daya alam dan hutan dengan kearifan lokal. Dalam pengelolaan tanah adat Marga Sarampas ada istilah "Tanah Ajum Tanah Arah", yang bermakna pemberian tanah harus sesuai peruntukan, pemberian ini terdiri dari wilayah mana yang bisa dibuka sebagai peladangan dan perumahan. Tanah Ajum bermakna tanah bisa dibuka untuk perumahan bagi warga. Sementara Tanah Arah, berarti tanah bisa dibuka untuk bercocok tanam atau peladangan. Tanah berair untuk sawah dan tanah kering untuk bercocok tanam. ${ }^{13}$ Hak ini masih eksist, diakui, dihormati dan dilindungi sampai sekarang oleh Pemda Kabupaten Merangin.

Mengenai eksistensi dan apakah masyarakat hukum itu dikatakan oleh Ter Haar, yaitu di seluruh pulau-pulau Indonesia pada tingkatan rakyat bawah ada pergaulan hidup di dalam kelompok-kelompok yang berprilaku menjadi kesatuan terhadap dunia lahir dan batin. Kelompok-kelompok itu mempunyai tata organisasi yang tetap dan kekal serta orang- orang dalam kelompok itu masing-masing mengalami kehidupannya dalam kelompok sebagai hal yang sewajarnya, hal menurut kodrat alam. Tidak ada seorang pun dari meraka yangmempunyai pikiran akan kemungkinan pembubaran kelompok itu. Kelompok ini mempunyai pengurus sendiri, harta benda sendiri, milik keduniawan, milik gaib. Kelompok-kelompok demikianlah yang bersifat persekutuan hukum. ${ }^{14}$

${ }^{11}$ Nor Qomariah, Arah Baru Kebiijakan Dan Penegakan Hukum Konserpasi SDA Hayati Dan Ekosistemnya : Pengakuan Hukum Adat Dan Penegakan Hukum Adat Sebagai Alternatif Perlindungan Kawaasan Pelestarian Alam, Jakarta : Indonesian Center For Environmental Law, 2019, hal, 177.

${ }^{12}$ Rosdalina Bukido, Hukum Adat, Yogyakarta: Deepublish, 2017, hal 120.

${ }^{13}$ https://www.mongabay.co.id/2016/08/31/buah-manis-masyarakat-adat-serampas-dalam-menjaga-hutan/. diakses tanggal 26 Maret 2021.

${ }^{14}$ Igede A.B Wiranataa, Hukum Adaat Indonesia: Perkembanganya Dari Masa Ke Masa, Bandung: PTCitra AdityaBakti, 2005, hlm. 110 . 


\section{Penguasaan Hak Atas Tanah Masyarakat Hukum Adat Marga Sarampas}

Guna pelaksanaan hukum pertanahan nasional disamping permintaan MHA, maka pada tanggal 24 Juni 1999 diterbitkan Pemen Agraria/Kepala BPN No. 5 Tahun 1999 Tentang Pedoman Penyelesaian Masalah Hak Ulayat Masarakat Hukum Adat. Ketentuan itu memuat kebijaksanaan yang menjelaskan prinsip pengakuan terhadap hak ulayat dan hak-hak yang serupa itu dari masyarakat hukum adat sebagaimana yang dimaksud dalam Pasal 3 UUPA. Kebijaksaan itu meliputi:

1. Penyamaan persepsi mengenai hak ulayat;

2. Kriteria dan penentuan masih eksisnya hak ulayat dan hak-hak serupa dari MHA;

3. kewenangan hukum adat terhadap tahan ulayatnya.

Perlindungan hukum hak atas tanah MHA Marga Serampas ditegaskan dalam Perda Nomor 8 Tahun 2016, yaitu Masyarakat Hukum Adat Marga Sarampas berhak atas tanah-tanah, wilayah dan sumber daya alam yang mereka kuasai secara turun-temurun meliputi semua yang berada dipermukaan ataupun terkandung didalam tanah. Hak tersebut mencakup hak untuk memiliki, menggunakan, mengembangkan dan mengendalikan atas dasar kepemilikan turun temurun dan/atau cara-cara yang lain.

Pengelolaan tanah di MHA Marga Sarampas harus dijaga dan dilestarikan. Bagi warga yang ingin mendapatkan tanah terlebih dahulu harus melapor ke Depati (Pemimpin MHA Marga Sarampas). Jika warga akan membuka ladang dalam satu Pemimpin maka wajib memberikan biaya adat sebesar segantang (4 kg) beras dan satu ekor ayam. Apabila membuka ladang berbeda Pemimpin akan dikenakan denda adat berupa beras 20 gantang serta satu ekor kambing. Tanah di wilayah MHA Marga Sarampas hanya warga yang berhak atau bebas menggunakannya. Sementara jika orang luar tidak boleh mengurus tanah di wilayah Marga Sarampas. Apabila akan mengurus tanah wajib menjadiwarga Sarampas dan tidak diperkenankan membuka area baru. Demikian juga dengan memungut hasil dari tanah untuk kebutuhan sehari-hari. apabila diperuntukkan bagi kebutuhan warga lain maka hak pengelolaan tanah diambil. Dan warga lain yang menerima hasil atas tanah diberikan denda adat.

Pengakuan hukum hak atas tanah dan wilayah MHA Marga Sarampas terutama yang berada di Desa Rantau Kermas dimulai dari Perdes Nomor 1/Kades/RK/3/2000, disahkan 16 April 2000 dan ditujukan bagi warga MHA Marga Sarampas. Perdes ini membuat Hutan Adat tersebut mendapat perhatian dari Bupati Merangin Melalui Keputusan No. 146/Disbunhut/2015 memberikan eksistensi dan perlindungan serta penetapan hutan adat MHA Sarampas yang berada di Rantau Kermas seluas 130 ha. ${ }^{15}$

Penetapan atas hutan adat Serampas Desa Rantau Kermas oleh Bupati menjadi dasar dikeluarkannya Keputusan Menteri LHK Nomor: 6741/MENLHK-PSKL/KUM. 1/12/2016 dan Keputusan Menteri LHK Nomor 6745/MEN LHK-PSKL/KUM.1/12/ 2016 Tentang Penetapan Hutan Adat Marga Sarampas Desa Rantau Karmas. Pengakuan hak atas tanah berupa hutan adat oleh Pemerintah tentunya merupakan pengakuan terhadap hak asasi MHA Marga Sarampas. Tentunya ini diperlukan dalam hubungannya dengan hak-hak MHA, karena hak memiliki secara bersama erat hubungannya dengan masyarakat adat yang mempunyai karakteristik khusus hak komunal. ${ }^{16}$

Hak-hak konstitusional MHA seharusnya lebih dikedepankan dari pada hak-hak warga Negara biasa. Sebab MHA adalah warga negara yang memiliki hak-hak khusus secara tradisional. Secara teoritis diakui bahwa MHA sebagai warga negara perlu mendapatkan perlindungan, jaminan dan kepastian hukum tetapi dalam realita nasib dan satus sosial ekonomi mereka termarjinalkan. ${ }^{17}$

\section{SIMPULAN}

1. Keberadaan MHA bukan hanya telah memperoleh pengakuan secara konstitusional sebagaimana diatur dalam Pasal 18B ayat (2), melainkan perlindungannya lebih kuat lagi karena dipertegas dalam Pasal 28I tentang HAM.Hal ini menunjukkan bahwa keberadaan MHA telah diterima dalam kerangka hukum yang berlaku di Indonesia. Pengakuan dan Perlindungan terhadap MHA Marga Sarampas telah diatur dalam Perda Kab. Merangin Nomor 8 Tahun 2016 Tentang Pengakuan Dan Perlindungan Masyarakat Hukum Adat Marga Serampas. Hal ini berimplikasi pada Pemda Kab. Merangin mengakui eksistensi dan sekaligus memberikan pengakuan dan perlindungan hukum terhadap MHA Marga Sarampas.

2. Hak atas tanah MHA Marga Sarampas telah dikukuhkan dengan Keputusan Menteri LHK Nomor 6741/MENLHKPSKL/KUM.1/12/2016 dan Keptusan Menteri LHK Nomor6745/MENLHK-PSKL/KUM.1/12/2016 Tentang penetapan hutan Adat MHA Marga Sarampas di Desa Rantau Karmas. Dengan pemberian hak atas hutan adat ini maka MHA Marga Sarampas berhak mengelola, melindungi dan melestarikan hutan adat mereka dari kerusakan.

15 Nor Qomariah, Op.Cit., hal, 189.

${ }^{16}$ Dyah Ayu Widowati, Op.Cit hal. 40

${ }^{17}$ Jawahir Thontowi, Op.Cit, hal. 6. 


\section{DAFTAR PUSTAKA}

\section{Buku}

Dyah Ayu Widowati, dkk, Pengakuan Dan Perlindungan Hak Atas Tanah Masyarakat Hukum Adat Di Kawasan Hutan, Yogyakarta : Amongkarta, 2014.

I Gede AB Wiranataa, Hukum Adat Indonesia: Perkembangannya Dari Masa Ke Masa, Bandung: PT. Citra Aditya Bakti, 2005.

Ishaq, Metode Penelitian Hukum Dan Penulisan Skripsi, Thesis Serta Disertasi. Bandung: CV. Alfabeta, 2017.

Mukti Fajar ND Dan Yulianto Achmad, Dualisme Penelitian Hukum Normatif Dan Empiris, Yogyakarta: Pustaka Pelajar, 2017.

Rosdalina Bukido, Hukum Adat, Yogyakarta : Deepublish, 2017.

\section{Jurnal Dan Hasil Penelitian}

Faiq Tobroni, Menguatkan Hak Masyarakat Adat Atas Hutan Adat (Studi Putusan MK Nomor 35/PUU-X/2012), Jurnal Konsitusi : Vol. 10, No. 3, 2013.

Jawahir Thontowi, Pengaturan Masyarakat Hukum Adat Dan Implentasi Perlindungan Hak-Hak Tradisionalnya, Jurnal Hukum IUS QUIA IUSTUM, Vol. 1 No. 20, 2013.

Komnas HAM, Inkuiri Nasional Komisi Nasional Hak Asasi Manusia: Hak Masyarakat Hukum Adat Atas Wilayahnya di Kawasan Hutan, Jakarta : Komnas HAM, 2016.

Nor Qomariah, Arah Baru Kebijakan Dan Penegakan Hukum Konservasi SDA Hayati Dan Ekosistemnya: Pengakuan Hukum Adat Dan Penegakan Hukum Adat Sebagai Alternatip Parlindungan Kawaasan Pelastarian Alam, Jakarta : Indonesian Center For Environmental Law, 2019.

Safrin Salam, Perlindungan Hukum Masyarakat Hukum Adat Atas Hutan Adat, Jurnal Hukum Novelty, Vol. 7, No. 2, 2016.

Widiyanto, Menyegerakan Ketetapan Wilayah/Hutan Adat : Profil Masayrakat Hukum Adat Untuk Implementasi Putusan Mahkamah Konsitusi Nomor 35 Tahun 2012, Jakarta : HuMa, 2019.

Zayanti Mandasari, Politik Hukum Pengaturan Masyarakat Hukum Adat (Studi Putusan Mahkamah Konsitusi), Jurnal IUS QUIA IUSTUM, Vol. 21 No. 2, 2014, hal. 229.

\section{Peraturan Perundang-Undangan}

UUD RI Tahun 1945.

Peraturan Daerah Kabupaten Merangin Nomor 8 Tahun 2016 Tentang Pengakuan Dan Perlindungan Masyarakat Hukum Adat Marga Serampas.

Permeneg Agraria/Kepala Badan Pertanahan Nasional No. 5 Tahun 1999 Tentang Pedoman Penyelesaian Masalah Hak Ulayat MHA.

Undang-Undang Nomor 41 Tahun 1999 Tentang Kehutanan.

Undang-Undang Nomor 5 Tahun 1960 Tentang Pokok-Pokok Agraria.

Putusan Mahkamah Konsitusi (MK) Nomor 35/PUU-X/2012.

Website

https://www.mongabay.co.id/2016/08/31/buah-manis-masyarakat-adat-serampas-dalam-menjaga- hutan/. diakses tanggal 26 Maret 2021. 